This is an author produced version of a paper published in Journal of clinical periodontology. This paper has been peer-reviewed but does not include the final publisher proof-corrections or journal pagination.

Citation for the published paper:

Nilsson, Helena; Sanmartin Berglund, Johan; Renvert, Stefan. (2018).

Longitudinal evaluation of periodontitis and development of cognitive decline among older adults.. Journal of clinical periodontology, vol. 45, issue 10, p. null

URL: https://doi.org/10.1111/jcpe.12992

Publisher: Wiley

This document has been downloaded from MUEP (https://muep.mah.se) / DIVA (https://mau.diva-portal.org). 

adults.

Helena Nilsson ${ }^{1}$ Johan Sanmartin Berglund ${ }^{2,3}$ Stefan Renvert 2, 4, 5

${ }^{1}$ Maxillofacial Unit, Halland Hospital, Halmstad, Sweden

${ }^{2}$ Blekinge Institute of Technology, Karlskrona, Sweden

${ }^{3}$ Department of Clinical Sciences, Lund University, Lund, Sweden

${ }^{4}$ School of Health and Society, Kristianstad University, Kristianstad, Sweden

${ }^{5}$ School of Dental Science, Trinity College, Dublin, Ireland

Running title: periodontitis and cognitive decline

Keywords: Neurocognitive disorders; epidemiology; inflammation; older adults; periodontal diseases.

Correspondence: Dr Helena Nilsson

Specialisttandvården Region Halland

30185 Halmstad, Sweden

Phone: 004635134057

helena.i.nilsson@regionhalland.se

Fax +4635134064

\section{Source of funding}

This study was financially supported by Region Halland Sweden and Southern Health Care Region Sweden [220291]. The Swedish National Study on Ageing and Care, SNAC (www.snac.org) is financially supported by the Ministry of Health and Social Affairs, Sweden and the participating County Councils, Municipalities and University Departments. The authors declare that there are no conflicts of interest in this study.

\section{Abstract}


Aim: to determine whether having periodontitis is associated with cognitive decline among older adults.

Material and Methods: A prospective population study of older adults, Swedish National Study on Ageing and Care, (SNAC) provided repeated registrations of cognitive functions. Cognitive decline was defined as $\geq 3$-points deterioration from a predetermined level at baseline, using the Mini-Mental State Examination (MMSE).

Between 2001 and 2003, 715 individuals had a medical as well as a clinical and radiographic dental examination. The individuals were re-examined after 6 years. Periodontitis was defined as $\geq 4 \mathrm{~mm}$ bone loss at $\geq 30 \%$ of tooth sites. Social variables were captured from questionnaires. Results: The multivariate logistic regression analysis demonstrated a statistically significant association between prevalence of periodontitis and cognitive decline after adjustments of confounding factors of importance.

Conclusions: A history of periodontitis may be of importance for cognitive functions among older adults.

\section{Clinical Relevance}

Scientific rationale for the study: It is important to identify modifiable risk indicators for cognitive impairment and dementia. It has been proposed that diseases with an inflammatory background may have an impact on cognitive decline. Evidence of periodontitis as a putative risk indicator for the development of cognitive decline is limited.

Principal findings: This study showed that in a group of older adults in Sweden, a history of periodontal disease was an independent risk indicator for development of cognitive decline. Practical implications: Clinicians should provide adequate periodontal care to the elderly population. 


\section{Introduction}

Dementia has been defined as a clinical syndrome characterized by cognitive decline, sufficient to interfere with daily functioning (World Health Organization, 1992). The ongoing demographic transitions, leading to an increasing proportion of older adults, have a profound impact on the prevalence of dementia (Ferri et al., 2005; Prince et al., 2013). Hence, cognitive impairment and dementia are considered a major public health problem with large financial, human and social burdens (Murray et al., 2013; Wimo et al., 2017).

The most common form of dementia is Alzheimer's disease (AD) and modifiable risk factors related to $\mathrm{AD}$ are midlife obesity, midlife hypertension, diabetes, physical inactivity, smoking, low education and depression (Norton, Matthews, Barnes, Yaffe, \& Brayne, 2014). Life-style related factors such as alcohol consumption and a history of traumatic brain injury have also been associated to cognitive functions and dementia in elderly individuals (Li, Risacher, McAllister, \& Saykin, 2016; Peters, Peters, Warner, Beckett, \& Bulpitt, 2008) Recent systematic reviews suggest that older people with dementia have multiple oral health problems (Delwel et al., 2018; Gusman et al., 2018; Leira et al., 2017; Maldonado, Laugisch, Burgin, Sculean, \& Eick, 2018). However, studies on the relationship between periodontitis and cognitive decline are few but indicate an association (Gil-Montoya et al., 2014; Syrjala et al., 2012; Zenthofer et al., 2017). One possible explanation may be related to changes in daily functioning, associated with cognitive decline, affecting oral hygiene routines, resulting in higher plaque and bleeding index (Gil-Montoya, Sanchez-Lara et al., 2017; Zenthofer, Schroder, Cabrera, Rammelsberg, \& Hassel, 2014). Another possible explanation to the reported association between periodontitis and cognitive decline may be related to the influence of a peripheral inflammation (Kamer et al., 2008).

Higher brain amyloid load has been reported as a central feature of Alzheimer's disease and clinical attachment loss (CAL) $\geq 3 \mathrm{~mm}$ has been associated with higher brain amyloid- $\beta(\mathrm{A} \beta)$ 
load among elderly individuals (Kamer et al., 2015). In a recent case-control study, higher plasma $A \beta_{1-42}$ peptide concentrations were reported in individuals with severe periodontal disease compared to individuals with healthy periodontal status (Gil-Montoya, Barrios et al., 2017). Additionally, lipopolysaccharides from periodontal pathogens have been identified in the brain tissues of patients with Alzheimer's disease in post-mortem analysis (Poole, Singhrao, Kesavalu, Curtis, \& Crean, 2013) and serum IgG levels to periodontal microbiota has been associated to risk for incident Alzheimer's disease (Noble et al., 2014).

In a retrospective case control study a modest higher risk for dementia was reported among individuals with periodontitis after adjustment for sociodemographic characteristics and comorbidities (Lee et al., 2016). In a 3-year follow-up study a two-fold higher risk for cognitive decline was reported for individuals with severe periodontitis compared to individuals without periodontitis (Iwasaki et al., 2016). To further explore a potential association between periodontitis and cognitive decline additional longitudinal studies are, however, warranted. The objective of the present study was to determine whether a diagnosis of periodontitis in individuals $\geq 60$ years of age at baseline was associated with cognitive decline in a 6 year follow up study.

\section{Material and methods}

The Swedish National Study on Ageing and Care (SNAC) is a population-based, prospective and longitudinal study running at four research centres. At one of the research centres, SNACBlekinge, 2312 individuals were invited by mail to participate in the study. Aiming to represent the elderly population in Sweden a randomised selection was made from the Swedish civil registration database in the age cohorts, $60,66,72,78$. In the age cohorts $81,84,87$ (and older) all individuals in the community were invited to participate in the study. 
Those who did not reply were contacted by telephone (three attempts). In total, 1402 agreed to participate and were invited by mail to take part in a medical, psychological and dental examination performed in a research clinic by professionals specially trained for the purpose. The sample of older adults in the selected age cohorts (60-96 years at baseline 2001-2003) is followed over time and all live in Karlskrona, Sweden. In the present study, individuals were assigned to the young-old age group (60,66 years), the old age group (72,28 years) and the old-old age group (81 years and older). All participants signed informed consent. The Research Ethics Committee at Lund, Sweden approved the study (LU 604-00, LU 744-00).

\section{Definitions of variables}

The cognitive outcome variable, Mini-Mental State Examination (MMSE), (Folstein, Folstein, \& McHugh, 1975) was evaluated at baseline and at the six-year follow-up examinations. Information about the level of education was collected from questionnaire and categorised according to final school grade; elementary ( $\leq 9$ years) or higher education ( $>9$ years). Living conditions were grouped into living alone or living with someone. Body mass index was calculated and categorised according to World Health Organizations (WHO: s) definition (< 25 defined as underweight and normal, and pre-obese and obese $\geq 25$ ) (World Health Organization, 2003). Known ischemic heart disease was defined as previous percutaneous coronary intervention (PCI), coronary surgery, myocardial infarction or angina pectoris. Information about smoking habits were collected from a questionnaire:” Do you smoke, regularly, occasionally, former or never"? Level of alcohol consumption was evaluated with the Alcohol Use Disorder Identification Test, AUDIT, a self-reported screening developed by the WHO in order to assess alcohol consumption and its consequences. It contains ten items, resulting in a total test score of 40 points. The test has been validated (Saunders, Aasland, Babor, de la Fuente, J R, \& Grant, 1993). The cut-off for harmful drinking behaviour was set to $\geq 8$ points (Conigrave, Hall, \& Saunders, 1995). Information regarding traumatic brain injury was captured from questionnaires and categorised into head trauma with loss of 
consciousness: yes or no. Level of depression was evaluated using the MADRS (Montgomery-Åsberg Depression Rating Scale) (Asberg, Montgomery, Perris, Schalling, \& Sedvall, 1978) with the following cut-off: 0-6, absence of depression; 7-19, mild depression; 20-34 moderate depression; and 35 and above, severe depression. Outcomes from the sixyear follow-up were used.

\section{Dental examination}

All individuals received a comprehensive clinical and radiographic dental examination by one of the two experienced dental hygienists. The clinical examination included registration of number of teeth present, probing pocket depth (PPD) measured at four sites at all existing teeth using periodontal probes (CP-12 probes, HU Friedy Inc.Chicago, IL, USA). The deepest probing depth for each tooth was used to calculate the proportion of teeth with a PPD value $\geq$ $5 \mathrm{~mm}$. Bleeding on probing was likewise examined and the proportion of teeth with bleeding at any of the four surfaces was registered. Intra-class correlation (ICC) analysis result between randomly selected cases for double assessments regarding the reproducibility of PPD values at the deepest site between the two clinicians performing the examinations was $0.76(95 \%$ confidence interval (CI) $0.67,0.82 ; p<0.001)$. Panoramic radiographs were taken using an orthopantomograph (Instrumentarium Dental, OP 100; Tuusula, Finland) with a standard exposure of $75 \mathrm{kV} / 10 \mathrm{~mA}$. The extent of alveolar bone loss was evaluated at the mesial and distal aspect of each tooth. For the purpose, a millimeter graded transparent ruler, and $2 \mathrm{x}$ magnification viewer and a light box source were used. The number of readable interproximal sites was used to calculate the proportion of sites with distance from the cement-enamel junction (CEJ) to the alveolar bone level exceeding 4 and $5 \mathrm{~mm}$ respectively. In the statistical analysis, periodontal bone-loss, $\geq 4 \mathrm{~mm}$ distance from CEJ to marginal bone level on $\geq 30 \%$ of readable sites was used as an indicator of a history of periodontal disease. An experienced independent examiner masked to age, gender, dental and medical information performed all 
the radiographic measurements. Reliability analysis were done for the double readings of the X-rays. The ICC correlation coefficient for the distance between the apex and CEJ was 0.93 $(95 \% \mathrm{CI}=0,91-0,96, \mathrm{p}<0.01)$, based on a total of 91 observations, with a mean difference of $0,94 \mathrm{~mm}(\mathrm{SD} \pm 1,3)$

\section{Cognitive Test}

Mini-Mental State Examination, MMSE, one of the most widely used cognitive screening test was used. The test consists of 20 items and the total sum of the test scores is maximum 30 (worst to best) (Folstein et al., 1975). The test has been assessed with reliable change index (RCI) and a change of 2-3 is considered an actual change i.e. not caused by practice or measurement effects (Eslinger, Swan, \& Carmelli, 2003; Iverson, 1998; Tombaugh, 2005). In this study individuals with MMSE-score $<25$ at baseline were excluded and cognitive decline was defined as $\geq 3$-points deterioration from baseline to the six-year follow-up.

\section{Statistical analysis}

A statistical software program (IBM SPSS version 22.0, IBM Statistics, Amorak, NY,USA) was used for the analysis. Descriptive statistics were used to present the population. A Chisquare test for independence was performed to evaluate potential associations between the candidate explanatory co-variables and the dependent variable; experience of cognitive decline. The association between a history of periodontitis, defined as having periodontal bone-loss $\geq 4 \mathrm{~mm}$ distance from CEJ to marginal bone level on $\geq 30 \%$ of readable sites and baseline characteristics was analyzed using the Chi-square-test. Low age, high education, living with someone, never smoked, no traumatic brain injury, no ischemic heart disease, AUDIT $<8$ and $\mathrm{BMI} \geq 25$ were used as references in the multivariate logistic regression analysis. The impact of periodontal bone loss on the risk for cognitive decline was analyzed first univariate and thereafter the co-variables were added in blocks additionally based on 
area; demographic, medical and social. Odds ratio (OR), 95\% confidence interval (CI) and pvalues were calculated; p-values $<0.05$ were regarded as statistically significant.

\section{Results}

The study population consisted of individuals who were examined both at baseline (20012003), and at the six-year follow-up (2007-2009). At baseline, 1402 individuals were examined. At the 6-year examination 452 of the baseline population had died, $110(11,6 \%)$ refused further participation, 22 individuals denied participation in the cognitive test, 14 had only completed parts of the test due to functional disabilities (visual or hearing difficulties, paresis) and 5 choose to abort before the test was fulfilled. After exclusion of individuals with MMSE-score $<25$ at baseline, 715 individuals remained. In order to moderate for the potential influence of depression on the cognitive test-outcome at the six-year follow-up, additional 11 individuals with moderate and severe depression according to Svanborg $(\geq 20$, MADRS) at the six-year follow-up examination were excluded. Thus, 704 individuals were available for evaluation. One-hundred fifteen individuals experienced $a \geq 3$ points decline in MMSE-results during the six-year follow-up. Such a decline in cognitive function was significantly associated with high age, elementary education, living alone, experience of ischemic heart disease, BMI $<25$, being edentulous, having 1-19 teeth and bone loss $\geq 4 \mathrm{~mm}$ at $\geq 30 \%$ of readable sites (Table 1$)$.

Data on dental status were available in 662 of the 704 selected individuals (94\%). In 566 individuals, panoramic radiographs were available for analysis of alveolar bone loss in which $214(38 \%)$ had findings of bone loss $\geq 4 \mathrm{~mm}$ at $\geq 30 \%$ of readable sites. Bone loss $\geq 4 \mathrm{~mm}$ at $\geq$ $30 \%$ of readable sites was significantly associated with cognitive decline but also with high age, lower education, male gender, current or former smoker, experience of ischemic heart disease, living alone, fewer teeth (1-19) and presence of pockets ( $\geq 5 \mathrm{~mm}$ on $30 \%$ of teeth) (Table 2). The unadjusted odds ratio (OR) for participants with bone-loss $\geq 4 \mathrm{~mm}$ at $\geq 30 \%$ of 
readable sites compared to those without for incident cognitive decline were 2.8 (CI 1.7-4.5) and in the fully adjusted model 2.2 (CI 1.2-3.8), (Table 3). Other variables reaching statistical significance in the fully adjusted model were age, education and BMI.

\section{Discussion}

The main finding of this prospective longitudinal cohort study was that periodontitis, defined as bone loss $\geq 4 \mathrm{~mm}$ at $\geq 30 \%$ of readable sites registered at panoramic $\mathrm{x}$-rays at baseline, was an independent risk indicator for cognitive decline after 6 years.

Cognitive impairment and neurocognitive disorders have a multifactorial aetiology and in the present study adjustments were made for demographic, lifestyle and medical factors. It is well known that the impact of different risk factors most likely starts long before signs of cognitive decline are clinically evident. Therefore, in this type of study the use of alveolar-bone loss is relevant for defining a course of periodontal disease. Previous studies evaluating cognitive function and dementia in relation to oral health parameters are mainly cross-sectional. Hence, the possibility to discuss causality is limited. As cognitive decline progresses, changes in daily functioning will emerge, influencing factors such as diet and oral hygiene. Such changes may influence the risk for caries and gingivitis in these patients. In the present study, only individuals with MMSE $\geq 25$ at baseline were included and therefore a possible causal relationship between a history of periodontitis and cognitive decline can be suggested. In light of the current trends, with an increasing proportion of elderly, and apparently increasing prevalence of dementia, our findings may be of importance also in a public health perspective. Current available medication exerts no clear effect on the clinical course of dementia and no curative treatments are available. Identifying and moderate modifiable risk factors is therefore critical as they may prevent or postpone the clinical onset of dementia. Few studies have evaluated the impact of periodontitis on the risk for cognitive decline longitudinally. In a recent follow-up study over 3 years, a higher risk for cognitive decline, 
estimated as a decrease of $\geq 3$ points in MMSE score, was demonstrated, among individuals with severe periodontitis, defined as $\geq 2$ interproximal sites with clinical attachment loss of $\geq$ $6 \mathrm{~mm}$ and $\geq 1$ interproximal sites with probing depth $\geq 5 \mathrm{~mm}$ (CDC/AAP), compared to individuals without periodontitis, after controlling for baseline health characteristics of importance (Iwasaki et al., 2016). These results are consistent with our findings. Our results are also consistent with the ones reported by Lee and coworkers (Lee et al., 2016) demonstrating that individuals with periodontitis had a higher risk of developing dementia. However, our results are in contrast to the ones reported by Arrive' and coworkers who were unable to find an association between periodontitis and dementia in a prospective follow-up study, over 15 years, in a sample of individuals aged 60-88 years, living in France(Arrive et al., 2012). A possible explanation to the conflicting results may be related to the definition of periodontitis used. In the study by Arrive' and coworkers, presence of periodontitis was evaluated using the Community Periodontal Index (CPI) (World Health Organization, 1997), which is considered as a screening tool for periodontal disease, whereas in our study periodontitis was based on actual bone loss, measured on radiographs. This underline the importance of including attachment or bone loss in the definition of periodontitis, reflecting a life-time burden of periodontal disease, when exploring a potential association to systemic diseases. A strength of our study is that a large cohort of elderly individuals were followed for a period of six years. The randomised population-based sample may also allow us to generalize the results even though the risk for selective attrition must be considered. Individuals who drop out for reasons other than death are often older and more functionally impaired. Individuals that are ill and frail may be less likely to respond and come to the research centre and in this study that is a prerequisite, as the final results rely on data from panoramic x-rays. When comparing baseline characteristics, for the group not selected or available in the final analysis, we found this group to be older, and more likely; having lower 
education, living alone, having ischemic heart disease, having BMI $<25$, having less teeth (119) and being edentulous, more likely having bone-loss ( $\geq 4 \mathrm{~mm}$ distance from CEJ to marginal bone level on $\geq 30 \%$ of readable sites) and pockets according to category ( $\geq 5 \mathrm{~mm}$ on $30 \%$ of teeth), than the selected study cohort (704). These results suggest, in addition to the exclusion of individuals with lower cognitive test outcome (MMSE <25) at baseline, that any influence of selective attrition would be that the results are underestimated. A methodological strength with the present study is that the same research team has followed the individuals during the whole study period. Other studies have added cognitive data to pre-existing oral health data (Stein, Desrosiers, Donegan, Yepes, \& Kryscio, 2007; Stein, Kryscio, Desrosiers, Donegan, \& Gibbs, 2010) or used self-reported data regarding oral health status (Batty et al., 2013; Gatz et al., 2006; Paganini-Hill, White, \& Atchison, 2012)

Mini-Mental State Examination (MMSE) is a suitable instrument for screening for cognitive abilities in epidemiological research since it is validated and easy to administer. However, it also has some well-known limitations. The outcome relies on language skills and therefore individuals with hearing and visual disabilities had to be excluded even if they were cognitively healthy. Additionally, its ability to differentiate between subtypes of cognitive impairment and dementia has been questioned (Tombaugh \& McIntyre, 1992). The study therefore needs to be repeated with other cognitive tests and with different subtypes of dementia. The underlying mechanisms explaining the association between periodontitis and cognitive deterioration are not clear and may vary between different types of dementia. Both vascular dementia and dementia of Alzheimer's type can be associated with systemic inflammation and since increasing evidence suggests that periodontitis may induce a systemic inflammatory burden, this could be a connecting pathway(Paraskevas, Huizinga, \& Loos, 2008; Passoja et al., 2010). The association between experience of ischemic heart disease and periodontitis reported in the present study support this hypothesis. 
The present study demonstrated that a history of periodontitis is associated with decline in cognitive functions after 6 years follow up, which may indicate that periodontitis is a risk indicator for cognitive decline. Long term intervention studies are warranted to evaluate if periodontal treatment can influence progression of cognitive decline.

\section{References}

Arrive, E., Letenneur, L., Matharan, F., Laporte, C., Helmer, C., Barberger-Gateau, P., . . Dartigues, J. F. (2012). Oral health condition of french elderly and risk of dementia: A 
longitudinal cohort study. Community Dentistry and Oral Epidemiology, 40(3), 230-238. 10.1111/j.1600-0528.2011.00650.x; 10.1111/j.1600-0528.2011.00650.x

Asberg, M., Montgomery, S. A., Perris, C., Schalling, D., \& Sedvall, G. (1978). A comprehensive psychopathological rating scale. Acta Psychiatrica Scandinavica.Supplementum, (271)(271), 5-27.

Batty, G. D., Li, Q., Huxley, R., Zoungas, S., Taylor, B. A., Neal, B., . . VANCE Collaborative group. (2013). Oral disease in relation to future risk of dementia and cognitive decline: Prospective cohort study based on the action in diabetes and vascular disease: Preterax and diamicron modified-release controlled evaluation (ADVANCE) trial. European Psychiatry: The Journal of the Association of European Psychiatrists, 28(1), 49-52. 10.1016/j.eurpsy.2011.07.005 [doi]

Conigrave, K. M., Hall, W. D., \& Saunders, J. B. (1995). The AUDIT questionnaire: Choosing a cut-off score. alcohol use disorder identification test. Addiction (Abingdon, England), 90(10), 1349-1356.

Delwel, S., Binnekade, T. T., Perez, R S G M, Hertogh, C M P M, Scherder, E. J. A., \& Lobbezoo, F. (2018). Oral hygiene and oral health in older people with dementia: A comprehensive review with focus on oral soft tissues. Clinical Oral Investigations, 22(1), 93-108. 10.1007/s00784-017-2264-2 [doi]

Eslinger, P. J., Swan, G. E., \& Carmelli, D. (2003). Changes in mini-mental state exam in community-dwelling older persons over 6 years: Relationship to health and neuropsychological measures. Neuroepidemiology, 22(1), 23-30. 67113 [doi] 
Ferri, C. P., Prince, M., Brayne, C., Brodaty, H., Fratiglioni, L., Ganguli, M., . . Alzheimer's Disease International. (2005). Global prevalence of dementia: A delphi consensus study. Lancet, 366(9503), 2112-2117. 10.1016/S0140-6736(05)67889-0

Folstein, M. F., Folstein, S. E., \& McHugh, P. R. (1975). "Mini-mental state". A practical method for grading the cognitive state of patients for the clinician. Journal of Psychiatric Research, 12(3), 189-198.

Gatz, M., Mortimer, J. A., Fratiglioni, L., Johansson, B., Berg, S., Reynolds, C. A., \& Pedersen, N. L. (2006). Potentially modifiable risk factors for dementia in identical twins. Alzheimer's \& Dementia : The Journal of the Alzheimer's Association, 2(2), 110117. 10.1016/j.jalz.2006.01.002

Gil-Montoya, J. A., Barrios, R., Santana, S., Sanchez-Lara, I., Pardo, C. C., Fornieles-Rubio, F., . . Burgos, J. S. (2017). Association between periodontitis and amyloid-beta peptide in elderly people with and without cognitive impairment. Journal of Periodontology, , 110. 10.1902/jop.2017.170071 [doi]

Gil-Montoya, J. A., Sanchez-Lara, I., Carnero-Pardo, C., Fornieles, F., Montes, J., Vilchez, R., .. . Bravo, M. (2014). Is periodontitis a risk factor for cognitive impairment and dementia? A case-control study. Journal of Periodontology, , 1-14. 10.1902/jop.2014.140340 [doi]

Gil-Montoya, J. A., Sanchez-Lara, I., Carnero-Pardo, C., Fornieles-Rubio, F., Montes, J., Barrios, R., . . Bravo, M. (2017). Oral hygiene in the elderly with different degrees of cognitive impairment and dementia. Journal of the American Geriatrics Society, 65(3), 642-647. 10.1111/jgs.14697 [doi] 
Gusman, D. J. R., Mello-Neto, J. M., Alves, B. E. S., Matheus, H. R., Ervolino, E., Theodoro, L. H., \& de Almeida, J. M. (2018). Periodontal disease severity in subjects with dementia: A systematic review and meta-analysis. Archives of Gerontology and Geriatrics, 76, 147-159. S0167-4943(18)30035-9 [pii]

Iverson, G. L. (1998). Interpretation of mini-mental state examination scores in communitydwelling elderly and geriatric neuropsychiatry patients. International Journal of Geriatric Psychiatry, 13(10), 661-666. AID-GPS838>3.0.CO;2-0 [pii]

Iwasaki, M., Yoshihara, A., Kimura, Y., Sato, M., Wada, T., Sakamoto, R., . . Matsubayashi, K. (2016). Longitudinal relationship of severe periodontitis with cognitive decline in older japanese. Journal of Periodontal Research, 51(5), 681-688. 10.1111/jre.12348 [doi]

Kamer, A. R., Craig, R. G., Dasanayake, A. P., Brys, M., Glodzik-Sobanska, L., \& de Leon, M. J. (2008). Inflammation and alzheimer's disease: Possible role of periodontal diseases. Alzheimer's \& Dementia : The Journal of the Alzheimer's Association, 4(4), 242-250. 10.1016/j.jalz.2007.08.004 [doi]

Kamer, A. R., Pirraglia, E., Tsui, W., Rusinek, H., Vallabhajosula, S., Mosconi, L., . . de Leon, M. J. (2015). Periodontal disease associates with higher brain amyloid load in normal elderly. Neurobiology of Aging, 36(2), 627-633.

10.1016/j.neurobiolaging.2014.10.038 [doi]

Lee, Y. T., Lee, H. C., Hu, C. J., Huang, L. K., Chao, S. P., Lin, C. P., . . Chen, C. C. (2016). Periodontitis as a modifiable risk factor for dementia: A nationwide population-based cohort study. Journal of the American Geriatrics Society, 10.1111/jgs.14449 [doi] 
Leira, Y., Dominguez, C., Seoane, J., Seoane-Romero, J., Pias-Peleteiro, J. M., Takkouche, B., . . . Aldrey, J. M. (2017). Is periodontal disease associated with alzheimer's disease? A systematic review with meta-analysis. Neuroepidemiology, 48(1-2), 21-31. $10.1159 / 000458411$ [doi]

Li, W., Risacher, S. L., McAllister, T. W., \& Saykin, A. J. (2016). Traumatic brain injury and age at onset of cognitive impairment in older adults. Journal of Neurology, 263(7), 12801285. $10.1007 / \mathrm{s} 00415-016-8093-4$ [doi]

Maldonado, A., Laugisch, O., Burgin, W., Sculean, A., \& Eick, S. (2018). Clinical periodontal variables in patients with and without dementia-a systematic review and meta-analysis. Clinical Oral Investigations, 10.1007/s00784-018-2523-x [doi]

Murray, C. J., Atkinson, C., Bhalla, K., Birbeck, G., Burstein, R., Chou, D., . . . U S Burden of Disease Collaborators. (2013). The state of US health, 1990-2010: Burden of diseases, injuries, and risk factors. Jama, 310(6), 591-608. 10.1001/jama.2013.13805 [doi]

Noble, J. M., Scarmeas, N., Celenti, R. S., Elkind, M. S., Wright, C. B., Schupf, N., \& Papapanou, P. N. (2014). Serum IgG antibody levels to periodontal microbiota are associated with incident alzheimer disease. PloS One, 9(12), e114959. 10.1371/journal.pone.0114959 [doi]

Norton, S., Matthews, F. E., Barnes, D. E., Yaffe, K., \& Brayne, C. (2014). Potential for primary prevention of alzheimer's disease: An analysis of population-based data. The Lancet.Neurology, 13(8), 788-794. 10.1016/S1474-4422(14)70136-X [doi]

Paganini-Hill, A., White, S. C., \& Atchison, K. A. (2012). Dentition, dental health habits, and dementia: The leisure world cohort study. Journal of the American Geriatrics Society, 60(8), 1556-1563. 10.1111/j.1532-5415.2012.04064.x [doi] 
Paraskevas, S., Huizinga, J. D., \& Loos, B. G. (2008). A systematic review and meta-analyses on C-reactive protein in relation to periodontitis. Journal of Clinical Periodontology, 35(4), 277-290. 10.1111/j.1600-051X.2007.01173.x [doi]

Passoja, A., Puijola, I., Knuuttila, M., Niemela, O., Karttunen, R., Raunio, T., \& Tervonen, T. (2010). Serum levels of interleukin-10 and tumour necrosis factor-alpha in chronic periodontitis. Journal of Clinical Periodontology, 37(10), 881-887. 10.1111/j.1600051X.2010.01602.x [doi]

Peters, R., Peters, J., Warner, J., Beckett, N., \& Bulpitt, C. (2008). Alcohol, dementia and cognitive decline in the elderly: A systematic review. Age and Ageing, 37(5), 505-512. 10.1093/ageing/afn095 [doi]

Poole, S., Singhrao, S. K., Kesavalu, L., Curtis, M. A., \& Crean, S. (2013). Determining the presence of periodontopathic virulence factors in short-term postmortem alzheimer's disease brain tissue. Journal of Alzheimer's Disease : JAD, 36(4), 665-677. 10.3233/JAD-121918 [doi]

Prince, M., Bryce, R., Albanese, E., Wimo, A., Ribeiro, W., \& Ferri, C. P. (2013). The global prevalence of dementia: A systematic review and metaanalysis. Alzheimer's \& Dementia : The Journal of the Alzheimer's Association, 9(1), 63-75.e2. 10.1016/j.jalz.2012.11.007 [doi]

Saunders, J. B., Aasland, O. G., Babor, T. F., de la Fuente, J R, \& Grant, M. (1993). Development of the alcohol use disorders identification test (AUDIT): WHO collaborative project on early detection of persons with harmful alcohol consumption--II. Addiction (Abingdon, England), 88(6), 791-804. 
Stein, P. S., Desrosiers, M., Donegan, S. J., Yepes, J. F., \& Kryscio, R. J. (2007). Tooth loss, dementia and neuropathology in the nun study. Journal of the American Dental Association (1939), 138(10), 1314-22; quiz 1381.

Stein, P. S., Kryscio, R. J., Desrosiers, M., Donegan, S. J., \& Gibbs, M. B. (2010). Tooth loss, apolipoprotein E, and decline in delayed word recall. Journal of Dental Research, 89(5), 473-477. 10.1177/0022034509357881

Syrjala, A. M., Ylostalo, P., Ruoppi, P., Komulainen, K., Hartikainen, S., Sulkava, R., \& Knuuttila, M. (2012). Dementia and oral health among subjects aged 75 years or older. Gerodontology, 29(1), 36-42. 10.1111/j.1741-2358.2010.00396.x; 10.1111/j.17412358.2010.00396.x

Tombaugh, T. N. (2005). Test-retest reliable coefficients and 5-year change scores for the MMSE and 3MS. Archives of Clinical Neuropsychology: The Official Journal of the National Academy of Neuropsychologists, 20(4), 485-503. S0887-6177(04)00183-0 [pii]

Tombaugh, T. N., \& McIntyre, N. J. (1992). The mini-mental state examination: A comprehensive review. Journal of the American Geriatrics Society, 40(9), 922-935.

Wimo, A., Guerchet, M., Ali, G. C., Wu, Y. T., Prina, A. M., Winblad, B., . . Prince, M. (2017). The worldwide costs of dementia 2015 and comparisons with 2010. Alzheimer's \& Dementia : The Journal of the Alzheimer's Association, 13(1), 1-7. S15525260(16)30043-7 [pii]

World Health Organization. (1992). The ICD-10 classification of mental and behavioural disorders: Clinical descriptions and diagnostic guidelines. Geneva: World Health Organization. Retrieved from http://www.who.int/iris/handle/10665/37958 
World Health Organization. (1997). Oral health surveys: Basic methods, 4th ed. Geneva:

World Health Organization. Retrieved from http://apps.who.int/iris/handle/10665/41905

World Health Organization. (2003). Obesity and overweight. Retrieved from

https://web.archive.org/web/20111210035353/http:/www.who.int/dietphysicalactivity/pu blications/facts/obesity/en

Zenthofer, A., Baumgart, D., Cabrera, T., Rammelsberg, P., Schroder, J., Corcodel, N., \& Hassel, A. J. (2017). Poor dental hygiene and periodontal health in nursing home residents with dementia: An observational study. Odontology, 105(2), 208-213. 10.1007/s10266-016-0246-5 [doi]

Zenthofer, A., Schroder, J., Cabrera, T., Rammelsberg, P., \& Hassel, A. J. (2014). Comparison of oral health among older people with and without dementia. Community Dental Health, 31(1), 27-31.

Table 1

Characteristics of the study population at baseline divided into cognitive decliners, based on deterioration of $\geq 3 p$ from baseline to six-year follow-up using MMSE.

\begin{tabular}{|c|c|c|c|}
\hline & $\begin{array}{l}\text { Not fulfilling } \\
\text { criteria for cognitive } \\
\text { decline }{ }^{*} \\
\text { n }(\%)\end{array}$ & $\begin{array}{l}\text { Cognitive } \\
\text { decliners, } \geq 3 p \\
\text { MMSE } \\
\text { n (\%) }\end{array}$ & $\begin{array}{l}p- \\
\text { value }\end{array}$ \\
\hline \multicolumn{4}{|l|}{ Baseline characteristics } \\
\hline $\begin{array}{l}\text { Age } \\
60,66 \\
72,78 \\
81-96\end{array}$ & $\begin{array}{l}308(94) \\
165(80) \\
116(68)\end{array}$ & $\begin{array}{l}19(6) \\
42(20) \\
54(32)\end{array}$ & $<0.001$ \\
\hline $\begin{array}{l}\text { Gender } \\
\text { Female } \\
\text { Male }\end{array}$ & $\begin{array}{l}330(83) \\
259(84)\end{array}$ & $\begin{array}{l}67(17) \\
48(16)\end{array}$ & 0.6 \\
\hline $\begin{array}{l}\text { Education } \\
\text { Elementary } \\
\text { Higher }\end{array}$ & $\begin{array}{l}461(82) \\
116(94)\end{array}$ & $\begin{array}{l}101(18) \\
7(6)\end{array}$ & 0.001 \\
\hline $\begin{array}{l}\text { Living alone } \\
\text { Yes } \\
\text { No }\end{array}$ & $\begin{array}{l}167(78) \\
417(87)\end{array}$ & $\begin{array}{l}47(22) \\
63(13)\end{array}$ & 0.003 \\
\hline $\begin{array}{l}\text { Ischemic heartdisease } \\
\text { Yes } \\
\text { No }\end{array}$ & $\begin{array}{l}88(75) \\
501(85)\end{array}$ & $\begin{array}{l}29(25) \\
86(15)\end{array}$ & 0.007 \\
\hline $\begin{array}{l}\text { BMI } \\
\text { Underweight and normal }<25 \\
\text { Pre-obese and obese } \geq 25\end{array}$ & $\begin{array}{l}151(77) \\
429(86)\end{array}$ & $\begin{array}{l}44(23) \\
70(14)\end{array}$ & 0.006 \\
\hline Traumatic brain injury & & & \\
\hline
\end{tabular}




\begin{tabular}{|c|c|c|c|}
\hline $\begin{array}{l}\text { Yes } \\
\text { No }\end{array}$ & $\begin{array}{l}84(87) \\
501(83)\end{array}$ & $\begin{array}{l}13(13) \\
101(17)\end{array}$ & 0.4 \\
\hline $\begin{array}{l}\text { Smoking } \\
\text { Current or former } \\
\text { Never }\end{array}$ & $\begin{array}{l}277(85) \\
301(83)\end{array}$ & $\begin{array}{l}49(15) \\
62(17)\end{array}$ & 0.46 \\
\hline $\begin{array}{l}\text { Alcohol (Alcohol Use Disorders } \\
\text { Intervention Scale, AUDIT } \geq 8 \text { ) } \\
\text { Yes } \\
\text { No }\end{array}$ & $\begin{array}{l}19(95) \\
546(84)\end{array}$ & $\begin{array}{l}1(5) \\
105(16)\end{array}$ & 0.18 \\
\hline $\begin{array}{l}\text { Edentulous } \\
\text { Yes } \\
\text { No }\end{array}$ & $\begin{array}{l}48(74) \\
509(85)\end{array}$ & $\begin{array}{l}17(26) \\
88(15)\end{array}$ & 0.02 \\
\hline $\begin{array}{l}\text { Number of teeth (edentulous excluded) } \\
1-19 \\
20-32\end{array}$ & $\begin{array}{l}180(76) \\
329(91)\end{array}$ & $\begin{array}{l}56(24) \\
32(9)\end{array}$ & $<0.001$ \\
\hline $\begin{array}{l}\text { Pockets according to category } \\
0 \\
1=\geq 5 \mathrm{~mm} \text { on } 30 \% \text { of teeth }\end{array}$ & $\begin{array}{l}472(86) \\
33(80.5)\end{array}$ & $\begin{array}{l}78(14) \\
8(19.5)\end{array}$ & 0.35 \\
\hline $\begin{array}{l}\text { Bleeding on probing }(\mathrm{Bop}) \\
0 \\
1=\geq 30 \% \text { of teeth }\end{array}$ & $\begin{array}{l}350(87) \\
155(82)\end{array}$ & $\begin{array}{l}52(13) \\
34(18)\end{array}$ & 0.1 \\
\hline $\begin{array}{l}\text { Bone-loss } \\
0 \\
1=\geq 4 \mathrm{~mm} \text { distance from CEJ to marginal bone } \\
\text { level on } \geq 30 \% \text { of readable sites }\end{array}$ & $\begin{array}{l}319(91) \\
166(78)\end{array}$ & $\begin{array}{l}33(9) \\
48(22)\end{array}$ & $<0.001$ \\
\hline
\end{tabular}

* Stable or minor cognitive decline (1-2p MMSE)

Table 2.

Characteristics of the study population at baseline divided into individuals having periodontal bone-loss, $\geq 4 \mathrm{~mm}$ distance from CEJ to marginal bone level on $\geq 30 \%$ of readable sites

\begin{tabular}{|l|l|l|l|}
\hline & $\begin{array}{l}\text { Not fulfilling the } \\
\text { criteria for } \\
\text { periodontal bone- } \\
\text { loss } \\
\text { n (\%) }\end{array}$ & $\begin{array}{l}\text { Periodontal } \\
\text { bone-loss } \\
\text { n (\%) }\end{array}$ & $\begin{array}{l}\text { p- } \\
\text { value }\end{array}$ \\
\hline Baseline characteristics & & & \\
\hline $\begin{array}{l}\text { Age } \\
\mathbf{6 0 , 6 6}\end{array}$ & $204(72)$ & $78(28)$ & \\
\hline $\mathbf{7 2 , 7 8}$ & $105(62)$ & $65(38)$ & \\
\hline $\mathbf{8 1 - 9 6}$ & $43(38)$ & $71(62)$ & $<0.001$ \\
\hline $\begin{array}{l}\text { Gender } \\
\text { Female } \\
\text { Male }\end{array}$ & $213(67)$ & $105(33)$ & \\
\hline $\begin{array}{l}\text { Education } \\
\text { Elementary } \\
\text { Higher }\end{array}$ & $139(56)$ & $109(44)$ & $<0.01$ \\
\hline $\begin{array}{l}\text { Living alone } \\
\text { Yes } \\
\text { No }\end{array}$ & $271(60)$ & $183(40)$ & $<0.01$ \\
\hline $\begin{array}{l}\text { Ischemic heartdisease } \\
\text { Yes }\end{array}$ & $78(75)$ & $26(25)$ & \\
\hline & $87(55)$ & $70(45)$ & \\
\hline
\end{tabular}




\begin{tabular}{|c|c|c|c|}
\hline No & $310(65)$ & $169(35)$ & $<0.01$ \\
\hline $\begin{array}{l}\text { BMI } \\
\text { Underweight and normal }<25 \\
\text { Pre-obese and obese } \geq 25\end{array}$ & $\begin{array}{l}97(59) \\
254(63.5)\end{array}$ & $\begin{array}{l}68(41) \\
146(36.5)\end{array}$ & 0.3 \\
\hline $\begin{array}{l}\text { Traumatic brain injury } \\
\text { Yes } \\
\text { No }\end{array}$ & $\begin{array}{l}49(62) \\
302(62)\end{array}$ & $\begin{array}{l}30(38) \\
183(38)\end{array}$ & 0.97 \\
\hline $\begin{array}{l}\text { Smoking } \\
\text { Current or former } \\
\text { Never }\end{array}$ & $\begin{array}{l}143(54) \\
205(70)\end{array}$ & $\begin{array}{l}123(46) \\
87(30)\end{array}$ & $<0.001$ \\
\hline $\begin{array}{l}\text { Alcohol (Alcohol Use Disorders } \\
\text { Intervention Scale, AUDIT } \geq 8 \text { ) } \\
\text { Yes } \\
\text { No }\end{array}$ & $\begin{array}{l}9(50) \\
332(84)\end{array}$ & $\begin{array}{l}9(50) \\
193(16)\end{array}$ & 0.2 \\
\hline $\begin{array}{l}\text { Number of teeth } \\
1-19 \\
20-32\end{array}$ & $\begin{array}{l}96(43) \\
256(75)\end{array}$ & $\begin{array}{l}129(57) \\
85(25)\end{array}$ & $<0.001$ \\
\hline $\begin{array}{l}\text { Pockets according to category } \\
0 \\
1=\geq 5 \mathrm{~mm} \text { on } 30 \% \text { of teeth }\end{array}$ & $\begin{array}{l}341(66) \\
6(15)\end{array}$ & $\begin{array}{l}179(34) \\
34(85)\end{array}$ & $<0.001$ \\
\hline $\begin{array}{l}\text { Bleeding on probing (Bop) } \\
0 \\
1=\geq 30 \% \text { of teeth }\end{array}$ & $\begin{array}{l}244(64) \\
103(57)\end{array}$ & $\begin{array}{l}136(36) \\
77(43)\end{array}$ & 0.1 \\
\hline
\end{tabular}

Table 3. Multivariate logistic regression analysis for the outcome cognitive decline, based on deterioration $\geq 3 \mathrm{p}$ from baseline to six-year follow-up using MMSE, the odds ratio for periodontal bone-loss with additional adjustments for demographic, medical and social variables.

\begin{tabular}{|c|c|c|c|c|c|}
\hline & $\begin{array}{l}\text { Crude } \\
\text { model } \\
\mathrm{n}=566\end{array}$ & $\begin{array}{l}\text { Model } 1 \\
\mathrm{n}=566\end{array}$ & $\begin{array}{l}\text { Model } 2 \\
\mathrm{n}=558\end{array}$ & $\begin{array}{l}\text { Model } 3 \\
\mathrm{n}=557\end{array}$ & $\begin{array}{l}\text { Model } 4 \\
\mathrm{n}=530\end{array}$ \\
\hline Periodontal bone-loss & $\begin{array}{l}2.8 \\
(1.7-4.5)\end{array}$ & $\begin{array}{l}2 \\
(1.2-3.3)\end{array}$ & $\begin{array}{l}2 \\
(1.1-3.3)\end{array}$ & $\begin{array}{l}1.9 \\
(1.1-3.2)\end{array}$ & $\begin{array}{l}2.2 \\
(1.2-3.8)\end{array}$ \\
\hline $\begin{array}{l}\text { Age } \\
72,76 \\
81-96\end{array}$ & & $\begin{array}{l}3.2 \\
(1.7-6.1) \\
6.2 \\
(3.2- \\
12.1)\end{array}$ & $\begin{array}{l}2.8 \\
(1.4-5.4) \\
5.8 \\
(2.9-11.7)\end{array}$ & $\begin{array}{l}2.8 \\
(1.4-5.6) \\
5.5 \\
(2.7-11.1)\end{array}$ & $\begin{array}{l}2.8 \\
(1.4-5.6) \\
5.3 \\
(2.5-11.1)\end{array}$ \\
\hline Male & & $\begin{array}{l}1.1 \\
(0.6-1.8)\end{array}$ & $\begin{array}{l}1.0 \\
(0.6-1.7)\end{array}$ & $\begin{array}{l}1.1 \\
(0.6-1.9)\end{array}$ & $\begin{array}{l}1.0 \\
(0.5-1.8)\end{array}$ \\
\hline Living alone & & & $\begin{array}{l}1.1 \\
(0.6-2.1)\end{array}$ & $\begin{array}{l}1.1( \\
0.6-2.0)\end{array}$ & $\begin{array}{l}1.2 \\
(0.7-2.3)\end{array}$ \\
\hline Education, elementary & & & 3.3 & 3.8 & 5 \\
\hline
\end{tabular}




\begin{tabular}{|l|l|l|l|l|l|}
\hline & & & $\mathbf{( 1 . 3 - 8 . 7 )}$ & $\mathbf{( 1 . 4 - 1 0 . 2 )}$ & \multicolumn{1}{|c|}{$\mathbf{1 . 7 - 1 4 . 7 )}$} \\
\hline Ischemic heart disease & & & & $\begin{array}{l}1.2(0.6- \\
2.4)\end{array}$ & $\begin{array}{l}1.2(0.6- \\
2.3)\end{array}$ \\
\hline $\begin{array}{l}\text { Body Mass Index (BMI), underweight and } \\
\text { normal }<25\end{array}$ & & & & $\begin{array}{l}\mathbf{2 . 4 ( 1 . 4 -} \\
\mathbf{4 . 1})\end{array}$ & $\begin{array}{l}\mathbf{2 . 1 ( 1 . 2 -} \\
\mathbf{3 . 7})\end{array}$ \\
\hline Traumatic brain injury & & & & & $0.8(0.4-$ \\
& & & & & $1.9)$ \\
\hline Smoking, current or former & & & & & $\begin{array}{l}1.3(0.7- \\
\end{array}$ \\
\hline Alcohol, AUDIT $\geq 8$ & & & & & $0.3)$ \\
\hline
\end{tabular}

Logistic regression model, Model 1=adjustment for periodontal bone-loss, age and gender, Model 2=model 1+adjustment for living alone and education, Model 3=model 2+adjustment for ischemic heart disease and BMI, Model 4=adjustment for all variables.

Values in bold signify statistical significance $\mathrm{p}<0.05$. Confidence interval, CI $(95 \%)$

\section{Supplement}

Table 4

Characteristics of the study population at baseline divided into participants selected for final analysis (704) after 6 years follow-up and members of the baseline cohort not available for the final analysis (698).

\begin{tabular}{|c|c|c|c|}
\hline 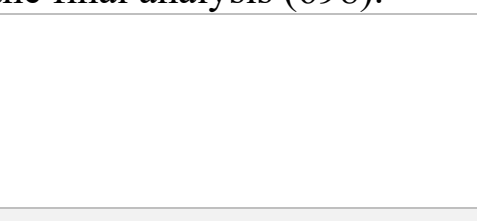 & Participants & $\begin{array}{l}\text { Members of the } \\
\text { baseline cohort } \\
\text { not available } \\
\text { for } 6 \text { years } \\
\text { follow-up }\end{array}$ & $\begin{array}{l}p- \\
\text { value }\end{array}$ \\
\hline \multicolumn{4}{|l|}{ Baseline characteristics } \\
\hline $\begin{array}{l}\text { Age } \\
60,66 \\
72,78 \\
81-96\end{array}$ & $\begin{array}{l}327(82) \\
207(60) \\
170(26)\end{array}$ & $\begin{array}{l}70(18) \\
136(40) \\
492(74)\end{array}$ & $<0.001$ \\
\hline $\begin{array}{l}\text { Gender } \\
\text { Female } \\
\text { Male }\end{array}$ & $\begin{array}{l}397(49) \\
307(52)\end{array}$ & $\begin{array}{l}419(51) \\
279(48)\end{array}$ & 0.2 \\
\hline $\begin{array}{l}\text { Education } \\
\text { Elementary } \\
\text { Higher }\end{array}$ & $\begin{array}{l}562(51) \\
123(67)\end{array}$ & $\begin{array}{l}531(49) \\
61(33)\end{array}$ & $<0.001$ \\
\hline $\begin{array}{l}\text { Living alone } \\
\text { Yes } \\
\text { No }\end{array}$ & $\begin{array}{l}214(37) \\
480(66)\end{array}$ & $\begin{array}{l}371(63) \\
252(34)\end{array}$ & $<0.001$ \\
\hline $\begin{array}{l}\text { Ischemic heartdisease } \\
\text { Yes } \\
\text { No }\end{array}$ & $\begin{array}{l}117(37) \\
587(54.5)\end{array}$ & $\begin{array}{l}203(63) \\
491(45.5)\end{array}$ & $<0.001$ \\
\hline $\begin{array}{l}\text { BMI } \\
\text { Underweight and normal }<25 \\
\text { Pre-obese and obese } \geq 25\end{array}$ & $\begin{array}{l}195(50) \\
499(60)\end{array}$ & $\begin{array}{l}197(50) \\
330(40)\end{array}$ & 0.001 \\
\hline $\begin{array}{l}\text { Traumatic brain injury } \\
\text { Yes } \\
\text { No }\end{array}$ & $\begin{array}{l}97(54) \\
602(50)\end{array}$ & $\begin{array}{l}84(46) \\
598(46)\end{array}$ & 0.4 \\
\hline $\begin{array}{l}\text { Smoking } \\
\text { Current or former } \\
\text { Never }\end{array}$ & $\begin{array}{l}326(55) \\
36351)\end{array}$ & $\begin{array}{l}264(45) \\
348(49)\end{array}$ & 0.1 \\
\hline $\begin{array}{l}\text { Edentulous } \\
\text { Yes } \\
\text { No }\end{array}$ & $\begin{array}{l}65(33) \\
596(63)\end{array}$ & $\begin{array}{l}134(67) \\
351(37)\end{array}$ & $<0.001$ \\
\hline
\end{tabular}




\begin{tabular}{|c|c|c|c|}
\hline $\begin{array}{l}\text { Number of teeth (edentulous excluded) } \\
1-19 \\
20-32\end{array}$ & $\begin{array}{l}236(52) \\
361(73)\end{array}$ & $\begin{array}{l}220(48) \\
131(27)\end{array}$ & $<0.001$ \\
\hline $\begin{array}{l}\text { Pockets according to category } \\
0 \\
1=\geq 5 \mathrm{~mm} \text { on } 30 \% \text { of teeth }\end{array}$ & $\begin{array}{l}550(65) \\
41(47)\end{array}$ & $\begin{array}{l}297(35) \\
47(53)\end{array}$ & 0.001 \\
\hline $\begin{array}{l}\text { Bleeding on probing (Bop) } \\
0 \\
\mathbf{1}=\geq \mathbf{3 0 \%} \text { of teeth }\end{array}$ & $\begin{array}{l}402(65) \\
189(60)\end{array}$ & $\begin{array}{l}220(35) \\
126(40)\end{array}$ & 0.2 \\
\hline $\begin{array}{l}\text { Bone-loss } \\
0 \\
1=\geq 4 \mathrm{~mm} \text { distance from CEJ to marginal bone } \\
\text { level on } \geq 30 \% \text { of readable sites }\end{array}$ & $\begin{array}{l}352(73) \\
214(57)\end{array}$ & $\begin{array}{l}128(27) \\
164(43)\end{array}$ & $<0.001$ \\
\hline
\end{tabular}

(The results presented for the group not available for the six years follow-up, regarding oral health variables, are based on individuals with dental examination at baseline) 